\title{
KHẨU PHẦ ĂN CỦA BẸNH NHÂN SUY THẬN CHẠY THẬN NHÂN TẠO TẠI BỆNH VIỆN ĐẠl HỌC Y HẢI PHÒNG NĂM 2021
}

\author{
Cáp Minh Đức ${ }^{\bowtie}$, Phạm Thị Như Quỳnh, Nguyễn Thị Thắm
}

Trường Đại học Y Dược Hải Phòng

Nghiên cứu mô tả cắt ngang trên 88 bệnh nhân suy thận chạy thận nhân tạo tại Bệnh viện Đại học Y Hải Phòng, từ tháng 01 năm 2021 đến tháng 05 năm 2021 nhằm đánh giá khẩu phần ăn của bệnh nhân. Sử dụng phương pháp hỏi ghi 24 giờ để điều tra khẩu phần ăn. Kết quả cho thấy, năng lượng khẩu phần ăn trung bình là 1470,54 $\pm 238,2$ kcal/ngày; lượng protein, lipid, carbohydrate trong khẩu phần lần lượt là $78,34 \pm 14,77$ g/ngày, 40,62 \pm 15,01 g/ngày, 199,63 \pm 43,82 g/ngày. Lượng protein, lipid đạt so với nhu cầu khuyến nghị, năng lượng đạt $87,99 \%$, carbohydrate đạt $88,45 \%$ nhu cầu khuyến nghị. Tỷ lệ \% các chất sinh năng lượng protein:lipid:carbohydrate = 21,64: 24,61: 53,75; tỷ lệ Ca/P 0,67; hàm lượng vitamin B2/1000kcal $0,54 \mathrm{mg}$ không cân đối so với nhu cầu khuyến nghị. Tỷ lệ Protein động vật/Protein tổng số 67,36\%; tỷ lệ Lipid thực vật/Lipid tổng số 39,98\%; hàm lượng vitamin B1, PP/1000kcal lần lượt là $1,01 \mathrm{mg}$ và $9,73 \mathrm{mg}$ cân đối so với nhu cầu khuyến nghị. Cần tăng cường công tác tư vấn chế độ ăn bệnh lý cho bệnh nhân.

Từ khóa: khẩu phần, suy thận, chạy thận nhân tạo.

\section{I. ĐẠT VẤN ĐÊ}

Suy thận mạn hay bệnh thận giai đoạn cuối là nguyên nhân gây tử vong đứng hàng thứ 9

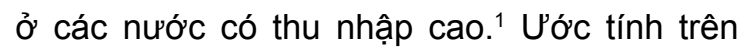
thế giới có $10 \%$ dân số bị ảnh hưởng bởi bệnh suy thận mạn và có hàng triệu người chết mỗi năm do không có điều kiện điều trị bệnh. ${ }^{2,3}$ Dinh dưỡng và chế độ ăn đóng vai trò rất quan trọng trong việc hỗ trợ điều trị và dự phòng các biến chứng của bệnh. Ăn nhạt và giảm protein trong khẩu phần là những biện pháp bảo vệ thận tối ưu trong điều trị làm chậm tiến triển của suy thận mạn đến giai đọan cuối. ${ }^{4}$ Kết quả nghiên cứu của các tác giả nước ngoài và trong nước đều cho thấy khẩu phần ăn của bệnh nhân không đáp ứng đủ so với nhu cầu khuyến nghị. Nghiên cứu cắt ngang của Wulandari $\mathrm{H}$ và cộng sự được thực hiện từ tháng 3 đến tháng

Tác giả liên hệ: Cáp Minh Đức

Trường Đại học Y Dược Hải Phòng

Email: minhduc.ydhp@gmail.com

Ngày nhận: 04/08/2021

Ngày được chấp nhận: 23/09/2021
4 năm 2015 trên 103 bệnh nhân tại Đơn vị lọc máu của Bệnh viện Sardjito, Indonesia, kết quả cho thấy năng lượng khẩu phần tiêu thụ trung bình trong khoảng 18,5 -27,1 kcal/kg cân nặng lý tưởng và lượng protein tiêu thụ trung bình trong khoảng $0,58-0,88 \mathrm{~g} / \mathrm{kg}$ cân nặng lý tưởng, thấp hơn nhiều so với khuyến nghị chế độăn uống cho bệnh nhân chạy thận nhân tạo. ${ }^{5}$ Nghiên cứu của Trần Thị Yến nhằm đánh giá khẩu phần thực tế và xác định một số rối loạn dinh dưỡng trên 99 bệnh nhân suy thận mạn chạy thận nhân tạo điều trị ngoại trú tại 2 bệnh viện tỉnh Thái Bình năm 2017 cho thấy năng lượng khẩu phần trung bình của bệnh nhân tại 2 bệnh viện là 1291,6 \pm 442,7 kcal/ngày. Trong đó, tỷ lệ bệnh nhân thiếu năng lượng khẩu phần chiếm $92,9 \%$ trên tổng số bệnh nhân, chưa có sự cân đối giữa lipid thực vật và lipid động vật. Tỷ lệ bệnh nhân được cung cấp đủ protein khẩu phần chiếm $17,2 \%$, thiếu protein khẩu phần chiếm $64,6 \%$. Hàm lượng caroten, sắt và kẽm trong khẩu phần ăn của bệnh nhân thiếu so với nhu cầu khuyến nghị. ${ }^{6}$ 
Bệnh viện Đại học $Y$ Hải Phòng mỗi năm quản lý và điều trị khoảng 100 bệnh nhân suy thận chạy thận nhân tạo, tuy nhiên cho tới nay chưa có nghiên cứu nào đánh giá khẩu phần ăn của bệnh nhân. Câu hỏi đặt ra là khẩu phần ăn của bệnh nhân có đáp ứng đủ so với nhu cầu khuyến nghị hay không? Từ thực tế đó chúng tôi tiến hành nghiên cứu này nhằm mục tiêu đánh giá khẩu phần ăn 24 giờ của bệnh nhân suy thận mạn chạy thận nhân tạo.

\section{II. ĐÓl TƯợNG VÀ PHƯƠNG PHÁP}

\section{1. Đối tượng}

Bệnh nhân suy thận mạn chạy thận nhân tạo tại Khoa thận Bệnh viện Đại học $Y$ Hải Phòng. Tiêu chuẩn lựa chọn, bệnh nhân từ đủ 18 tuổi trở lên tính đến thời điểm nghiên cứu và đồng ý tham gia nghiên cứu. Tiêu chuẩn loại trừ, phụ nữ có thai và bệnh nhân không thể trả lời được phỏng vấn do đang thở oxy, mắc các bệnh lý về tâm thần...

\section{Phương pháp}

\section{Thiết kế nghiên cứru}

Nghiên cứu mô tả cắt ngang.

Thời gian: Từ tháng 01 năm 2021 đến tháng 05 năm 2021.

\section{Địa điểm nghiên cứu}

Tại Khoa Thận nhân tạo, Bệnh viện Đại học Y Hải Phòng.

\section{Cỡ mẫu và chọn mẫu}

Áp dụng công thức cỡ mẫu cho việc ước lượng một giá trị trung bình:

$$
\mathrm{n}=\mathrm{Z}_{1-\alpha / 2}^{2} \cdot \frac{\mathrm{s}^{2}}{(\overline{\boldsymbol{X}} \cdot \varepsilon)^{2}}
$$

Trong đó:

n: Cỡ mẫu nghiên cứu.

$\bar{X}$, s: Lần lượt là giá trị năng lượng trung bình của khẩu phần và độ lệch chuẩn tham khảo từ nghiên cứu trước, $\bar{X} \pm \mathrm{s}=1.402,7 \pm 462,5$. $^{6}$ $\varepsilon$ : Là sai số tương đối giữa mẫu nghiên cứu và quần thể, lấy $\varepsilon=0,1$.

a: Mức ý nghĩa thống kê, chọn $\alpha=0,05 \rightarrow$ $Z_{1-\alpha / 2}=1,96$.

Tính được cỡ mẫu cho điều tra khẩu phần là 42 bệnh nhân. Thực tế chúng tôi tiến hành đánh giá khẩu phần ăn trên 88 bệnh nhân thỏa mãn các tiêu chí lựa chọn.

\section{Nội dung/chỉ số nghiên cứu}

Thông tin chung của bệnh nhân (tuổi, giới, nghề nghiệp, tần suất chạy thận nhân tạo), giá trị dinh dưỡng của khẩu phần 24h (năng lượng khẩu phần, cơ cấu khẩu phần các chất sinh năng lượng, không sinh năng lượng).

\section{Quy trình tiến hành nghiên cứu}

Lập danh sách tất cả bệnh nhân suy thận chạy thận nhân tạo tại Bệnh viện Đại học $Y$ Hải Phòng. Tập huấn cho nghiên cứu viên về công cụ điều tra và thống nhất các nội dung phỏng vấn, cách ghi thông tin vào phiếu hỏi. Nghiên cứu viên phỏng vấn trực tiếp bệnh nhân đến lọc máu tại Khoa Thận nhân tạo. Thời gian phỏng vấn từ 45 - 60 phút/người. Trước khi phỏng vấn bằng bộ phiếu được thiết kế sãn, nghiên cứu viên giới thiệu về mục đích của nghiên cứu, sự đồng thuận tham gia vào nghiên cứu cũng như giới thiệu qua nội dung của bộ câu hỏi. Sử dụng phương pháp hỏi ghi $24 \mathrm{~h}$ để điều tra khẩu phần ăn của bệnh nhân, bệnh nhân kể lại tỷ mỉ những gì đã ăn ngày hôm trước hoặc $24 \mathrm{~h}$ trước khi phỏng vấn. Mô tả chi tiết tất cả thức ăn, đồ uống đã được bệnh nhân tiêu thụ, kể cả cách chế biến, tên thực phẩm, tên hãng thực phẩm nếu là những thực phẩm chế biến sã̃n. Sử dụng quyển ảnh 500 món ăn thông dụng dành cho người trưởng thành Việt Nam để điều tra khẩu phần, giúp bệnh nhân dễ mô tả các kích cỡ thực phẩm đã sử dụng. ${ }^{7}$

\section{Tiêu chuẩn đánh giá}

- Đánh giá mức đáp ứng nhu cầu khuyến 
nghị: Theo nhu cầu khuyến nghị của Viện Dinh dưỡng năm 2016 dành cho bệnh nhân suy thận mạn chạy thận nhân tạo. ${ }^{8}$

- Đánh giá tính cân đối của khẩu phần: Theo nhu cầu khuyến nghị của Viện Dinh dưỡng năm 2016. ${ }^{9}$

\section{Xử lý số liệu}

Các phiếu điều tra được làm sạch trước khi nhập liệu và xử lý. Sử dụng hệ số sống chín quy đổi khẩu phần ăn $24 \mathrm{~h}$ của bệnh nhân ra thực phẩm sống sạch, ${ }^{10}$ sau đó nhập vào phần mềm Việt Nam Eiyokun để tính giá trị dinh dưỡng của khẩu phần ăn và phân tích bằng phần mềm Stata 14.2. Sử dụng các thuật toán thống kê mô tả: Tính giá trị trung bình, độ lệch chuẩn, tần số và tỷ lệ \%. Sử dụng các test thống kê y học: T-test để so sánh 2 giá trị trung bình, T-test ghép cặp để so sánh khẩu phần ăn thực tế với khẩu phần khuyến nghị của bệnh nhân.

\section{4. Đạo đức nghiên cứu}

Nghiên cứu được sự đồng ý của lãnh đạo Bệnh viện Đại học $Y$ Hải Phòng. Bệnh nhân tham gia nghiên cứu được giải thích rõ về mục đích nghiên cứu và tự nguyện tham gia nghiên cứu. Thông tin của bệnh nhân được bảo mật, chỉ phục vụ cho mục đích nghiên cứu. Kết quả nghiên cứu được thông báo cho Khoa Thận nhân tạo để từ đó có các biện pháp can thiệp nhằm cải thiện chế độ ăn của bệnh nhân.

\section{KÉT QUẢ}

Bảng 1. Thông tin chung của bệnh nhân $(n=88)$

\begin{tabular}{|c|c|c|c|}
\hline \multicolumn{2}{|c|}{ Thông tin } & Số lượng (n) & Tỷ lệ (\%) \\
\hline \multirow{2}{*}{ Giới tính } & Nam & 51 & 57,95 \\
\hline & Nữ & 37 & 42,05 \\
\hline \multirow{8}{*}{ Nhóm tuổi } & 18 - 29 tuổi & 6 & 6,82 \\
\hline & 30 - 39 tuổi & 9 & 10,26 \\
\hline & 40 - 49 tuổi & 19 & 21,59 \\
\hline & 50 - 59 tuổi & 18 & 20,45 \\
\hline & 60 - 69 tuổi & 26 & 29,55 \\
\hline & 70 - 79 tuổi & 9 & 10,23 \\
\hline & $\geq 80$ tuổi & 1 & 1,14 \\
\hline & $\overline{\boldsymbol{X}} \pm$ SD: $54,03 \pm 14,55$ & \multicolumn{2}{|c|}{ Min - Max: $19-81$} \\
\hline \multirow{2}{*}{$\begin{array}{c}\text { Tần suất } \\
\text { chạy thận nhân tạo }\end{array}$} & 2 lần/tuần & 1 & 1,14 \\
\hline & 3 lần/tuần & 87 & 98,86 \\
\hline
\end{tabular}

Tỷ lệ nam giới là 57,95\%, nữ giới là 42,05\%. Tuổi trung bình của bệnh nhân là 54,03 \pm 14,55 tuổi. Nhóm tuổi 60 - 69 chiếm tỉ lệ cao nhất $(29,55 \%)$, nhóm tuổi $\geq 80$ có tỉ lệ thấp nhất
(1,14\%). Bệnh nhân nhỏ tuổi nhất là 19 tuổi, cao nhất là 81 tuổi. 87 bệnh nhân chạy thận nhân tạo 3 lần/tuần (chiếm 98,86\%); chỉ có 1 bệnh nhân chạy thận nhân tạo 2 lần/tuần (chiếm 1,14\%). 


\section{Bảng 2. Cơ cấu khẩu phần ăn của bệnh nhân $(\mathrm{n}=88)$}

\section{Chỉ số dinh dưỡng}

Năng lượng và các chất sinh năng lượng

\begin{tabular}{|c|c|c|}
\hline \multicolumn{3}{|c|}{ Năng lượng và các chất sinh năng lượng } \\
\hline \multirow{2}{*}{ Năng lượng } & (kcal/ngày) & $1470,54 \pm 238,2$ \\
\hline & (kcal/kg/ngày) & $26,56 \pm 3,96$ \\
\hline \multirow{4}{*}{ Protein } & Tổng số (g) & $78,34 \pm 14,77$ \\
\hline & Thực vật (g) & $25,01 \pm 8,43$ \\
\hline & Động vật (g) & $53,29 \pm 15,54$ \\
\hline & Tổng số (g/kg/ngày) & $1,41 \pm 0,25$ \\
\hline \multirow{3}{*}{ Lipid } & Tổng số (g) & $40,62 \pm 15,01$ \\
\hline & Thực vật (g) & $15,85 \pm 10,39$ \\
\hline & Động vật (g) & $24,74 \pm 13,37$ \\
\hline \multicolumn{2}{|c|}{ Carbohydrate (g) } & $199,63 \pm 43,82$ \\
\hline \multicolumn{3}{|c|}{ Các chất không sinh năng lượng } \\
\hline \multicolumn{2}{|c|}{ Chất xơ $(\mathrm{g})$} & $5,89 \pm 2,80$ \\
\hline \multirow{6}{*}{ Chất khoáng } & $\mathrm{Na}(\mathrm{mg})$ & $1642,47 \pm 749,41$ \\
\hline & $\mathrm{K}(\mathrm{mg})$ & $1710,51 \pm 574,53$ \\
\hline & $\mathrm{P}(\mathrm{mg})$ & $917,02 \pm 205,28$ \\
\hline & $\mathrm{Ca}(\mathrm{mg})$ & $628,11 \pm 631,48$ \\
\hline & $\mathrm{Fe}(\mathrm{mg})$ & $12,42 \pm 4,23$ \\
\hline & $\mathrm{Zn}(\mathrm{mg})$ & $6,99 \pm 2,62$ \\
\hline \multirow{5}{*}{ Vitamin } & $A(\mu g)$ & $409,58 \pm 447,43$ \\
\hline & $\mathrm{PP}(\mathrm{mg})$ & $14,23 \pm 5,44$ \\
\hline & $C(\mathrm{mg})$ & $90,50 \pm 45,51$ \\
\hline & B1 (mg) & $1,46 \pm 0,61$ \\
\hline & B2 (mg) & $0,78 \pm 0,27$ \\
\hline
\end{tabular}

\section{Giá trị (đơn vị/ngày)}

$(\bar{X} \pm$ SD)

\footnotetext{
Năng lượng khẩu phần ăn trung bình của
bệnh nhân là $1470,54 \pm 238,2$ kcal. Lượng
protein, lipid, glicid trong khẩu phần lần lượt là
à $78,34 \pm 14,77 \mathrm{~g}, 40,62 \pm 15,01 \mathrm{~g}$ và $199,63 \pm$

Năng lượng khẩu phần ăn trung bình của
bệnh nhân là $1470,54 \pm 238,2$ kcal. Lượng
protein, lipid, glicid trong khẩu phần lần lượt là
là $78,34 \pm 14,77 \mathrm{~g}, 40,62 \pm 15,01 \mathrm{~g}$ và $199,63 \pm$

Năng lượng khẩu phần ăn trung bình của
bệnh nhân là $1470,54 \pm 238,2$ kcal. Lượng
protein, lipid, glicid trong khẩu phần lần lượt là
là $78,34 \pm 14,77 \mathrm{~g}, 40,62 \pm 15,01 \mathrm{~g}$ và $199,63 \pm$

Năng lượng khẩu phần ăn trung bình của
bệnh nhân là $1470,54 \pm 238,2$ kcal. Lượng
protein, lipid, glicid trong khẩu phần lần lượt là
là $78,34 \pm 14,77 \mathrm{~g}, 40,62 \pm 15,01 \mathrm{~g}$ và $199,63 \pm$ $43,82 \mathrm{~g}$.
}

Chất xơ trung bình trong khẩu phần ăn là $5,89 \pm 2,80 \mathrm{~g}$. Lượng chất khoáng trung bình trong khẩu phần: Canxi là $628,11 \pm 631,48 \mathrm{mg}$; Kẽm là 6,99 $\pm 2,62 \mathrm{mg}$; Sắt 16,05 \pm 4,61mg; Natri là $1642,47 \pm 74,41 \mathrm{mg}$; Kali là 1710,51 
\pm 574,53mg; Phospho là 917,02 $\pm 205,28 \mathrm{mg}$. $\quad 1,46 \pm 0,61 \mathrm{mg}$; Vitamin $\mathrm{B} 2$ 0,78 $\pm 0,27 \mathrm{mg}$; và

Các vitamin: Vitamin A 409,58 $\pm 447,43 \mu$; $\quad$ Vitamin C là 90,50 $\pm 45,51 \mathrm{mg}$.

Vitamin PP là $14,23 \pm 5,44 \mathrm{mg}$; Vitamin B1 là

Bảng 3. Mức đáp ứng của các chất dinh dưỡng so với nhu cầu khuyến $n g h i ̣ ~(n=88)$

\begin{tabular}{|c|c|c|c|c|}
\hline \multicolumn{2}{|c|}{ Chất dinh dưỡng } & $\begin{array}{l}\text { Kết quả } \\
\text { tính toán }\end{array}$ & $\begin{array}{c}\text { Nhu cầu } \\
\text { khuyến nghị }\end{array}$ & $\begin{array}{l}\text { Mú́c đáp úvng } \\
\text { nhu cầu (\%) }\end{array}$ \\
\hline \multicolumn{5}{|c|}{ Chất sinh năng lượng } \\
\hline \multicolumn{2}{|c|}{ Năng lượng (kcal/ngày) } & 1470,54 & $1671,13-1949,65$ & 87,99 \\
\hline \multicolumn{2}{|c|}{ Protein $(\mathrm{g})$} & 78,34 & 66,84 & Đạt \\
\hline \multicolumn{2}{|c|}{ Lipid (g) } & 40,62 & $37,14-55,70$ & Đạt \\
\hline \multicolumn{2}{|c|}{ Carbohydrate (g) } & 199,63 & $267,48-225,7$ & 88,45 \\
\hline \multicolumn{5}{|c|}{ Chất không sinh năng lượng } \\
\hline \multirow{4}{*}{ Chất khoáng } & $\mathrm{Na}(\mathrm{mg})$ & 1642,47 & $<2000$ & Đạt \\
\hline & $\mathrm{K}(\mathrm{mg})$ & 1710,51 & $2000-3000$ & 85,5 \\
\hline & $\mathrm{P}(\mathrm{mg})$ & 917,02 & $800-1200$ & Đạt \\
\hline & $\mathrm{Ca}(\mathrm{mg})$ & 628,11 & $1000-1500$ & 62,81 \\
\hline \multirow{5}{*}{ Vitamin } & $A(\mu g)$ & 409,58 & 600 & 68,26 \\
\hline & $\mathrm{PP}(\mathrm{mg})$ & 14,23 & 15 & 94,87 \\
\hline & C (mg) & 90,50 & 70 & Đạt \\
\hline & $\mathrm{B} 1$ (mg) & 1,46 & 1,4 & Đạt \\
\hline & B2 (mg) & 0,78 & 1,3 & 65,0 \\
\hline
\end{tabular}

Lượng protein, lipid trong khẩu phần ăn của bệnh nhân đạt so với nhu cầu khuyến nghị, năng lượng đạt $87,99 \%$, carbohydrate đạt $88,45 \%$ nhu cầu khuyến nghị. Lượng $\mathrm{Na}$,

Bảng 4. Tính cân đối của khẩu phần ăn 24h $(n=88)$

\begin{tabular}{cccc} 
Chỉ số & $\begin{array}{c}\text { Kết quả } \\
\text { tính toán }\end{array}$ & $\begin{array}{c}\text { Nhu cầu } \\
\text { khuyến nghị }\end{array}$ & $\begin{array}{c}\text { Đánh giá } \\
\text { tính cân đối }\end{array}$ \\
\hline Tỷ lệ P: L: G & $21,64: 24,61: 53,75$ & $16: 20-25: 55-65$ & Không \\
\hline Protein động vật /Protid tổng số \% & 67,36 & $\geq 50$ & Có \\
\hline
\end{tabular}

$\mathrm{P}$ đạt; lượng $\mathrm{K}$, Ca không đạt so với nhu cầu khuyến nghị. Vitamin $\mathrm{C}, \mathrm{B} 1$ đạt; vitamin $\mathrm{A}, \mathrm{PP}$, $B 2$ không đạt so với nhu cầu khuyến nghị. 


\begin{tabular}{cccc}
\hline Chỉ số & $\begin{array}{c}\text { Kết quả } \\
\text { tính toán }\end{array}$ & $\begin{array}{c}\text { Nhu cầu } \\
\text { khuyến nghị }\end{array}$ & $\begin{array}{c}\text { Đánh giá } \\
\text { tính cân đối }\end{array}$ \\
\hline Lipid thực vật/Lipid tổng số \% & 39,98 & $\geq 40$ & Có \\
\hline $\mathrm{Ca} / \mathrm{P}$ & 0,67 & $>0,8$ & Không \\
\hline $\mathrm{B} 1 / 1000 \mathrm{kcal}$ & 1,01 & 0,5 & Có \\
\hline $\mathrm{B} 2 / 1000 \mathrm{kcal}$ & 0,54 & 0,6 & Không \\
\hline $\mathrm{PP} / 1000 \mathrm{kcal}$ & 9,73 & 8,0 & Có \\
\hline
\end{tabular}

Tỷ lệ P: L: G; Ca/P; B2/1000 kcal không cân đối so với nhu cầu khuyến nghị. Tỷ lệ Protid động vật/Protid tổng số; Lipid thực vật/Lipid tổng số; B1/1000 kcal; PP/1000 kcal cân đối so với nhu cầu khuyến nghị.

\section{BÀN LUẪN}

Trong tổng số 88 bệnh nhân tham gia nghiên cứu, tỷ lệ bệnh nhân nam cao hơn bệnh nhân nữ $(57,95 \%$ so với $42,05 \%)$. Kết quả nghiên cứu của chúng tôi cho thấy tuổi trung bình của bệnh nhân là $54,03 \pm 14,55$ tuổi, cao nhất là 81 tuổi và thấp nhất là 19 tuổi, bệnh nhân dưới 60 tuổi chiếm 59,1\%, tương đương với tuổi trung bình của bệnh nhân trong nghiên cứu của Segall L và cộng sự (2009) tại Romania là $53,9 \pm 13,7$ tuổi1 và thấp hơn tuổi trung bình của bệnh nhân tại nghiên cứu của Beddhu $S$ và cộng sự tại Israel (71,0 \pm 10,7 tuổi). ${ }^{12}$

Theo khuyến nghị của Hiệp hội dinh dưỡng Lâm sàng và Chuyển hóa châu Âu (ESPEN) năm 2021 dành cho bệnh nhân suy thận mạn, nhu cầu năng lượng $30-35 \mathrm{kcal} / \mathrm{kg} / \mathrm{ngày}$, protein $0,6-0,8 \mathrm{~g} / \mathrm{kg} / \mathrm{ngày} . . .{ }^{13}$ Trong nghiên cứu này, chúng tôi sử dụng nhu cầu khuyến nghị của Viện Dinh dưỡng năm 2016 để đánh giá khẩu phần ăn của bệnh nhân. ${ }^{8}$

Năng lượng khẩu phần

Kết quả nghiên cứu cho thấy năng lượng khẩu phần trung bình của bệnh nhân suy thận mạn chạy thận nhân tạo là 1470,54 — 238,2 kcal/ người/ngày, năng lượng khẩu phần đạt $87,99 \%$ so với khuyến nghị. Kết quả của chúng tôi tương đồng với nghiên cứu của Inaiana Marques Filizola VAZ và cộng sự tại Bồ Đào Nha (2015) trên 344 bệnh nhân suy thận mạn chạy thận nhân tạo với mức năng lượng khẩu phần trung bình là 1490,30 kcal/ngày; năng lượng theo cân nặng là $25,4 \pm 7,4 \mathrm{kcal} / \mathrm{kg} / \mathrm{ngày}^{14}$ và cao hơn nghiên cứu của Trần Thị Yến tại 2 bệnh viện của tỉnh Thái Bình (2018) với năng lượng trung bình của 197 đối tượng là 1291,6 4 442,7 kcal/ngày. ${ }^{6}$

\section{Lượng protein khẩu phần}

Theo nhu cầu khuyến nghị của Viện Dinh dưỡng năm 2016 dành cho bện nhân suy thận mạn chạy thận nhân tạo là $1,2 \mathrm{~g} / \mathrm{kg}$ cân nặng/ ngày, chúng tôi tính được nhu cầu khuyến nghị protein của bệnh nhân là 66,84 g/người/ngày. Trong khi đó, lượng protein trung bình trong khẩu phần là $78,34 \pm 14,77$ g/người/ngày, cao hơn so với nhu cầu khuyến nghị. Kết quả này cao hơn lượng protein trung bình khẩu phần trong nghiên cứu của Trần Thị Yến tại 2 bệnh viện ở Thái Bình (2018) là 61,2 \pm 24,2g/người/ ngày, ${ }^{6}$ nghiên cứu của Trần Khánh Thu và cộng sự tại Bệnh viện đa khoa Thái Bình (2017) là $56,3 \pm 9,4$ g/ngày, ${ }^{15}$ nghiên cứu của Hee-Sook L và cộng sự tại Hàn Quốc năm 2015 là 63,4 I $17,5 \mathrm{~g}$ g/người/ngày. ${ }^{16}$

Lượng lipid khẩu phần 
Lượng lipid trung bình trong khẩu phần là 40,62 $\pm 15,01 \mathrm{~g} / \mathrm{người/ngày,} \mathrm{đạt} \mathrm{so} \mathrm{với} \mathrm{nhu} \mathrm{cầu}$ khuyến nghị. Kết quả này cao hơn lượng lipid trung bình khẩu phần trong nghiên cứu tại 2 bệnh viện ở Thái Bình (2018) 33,7 \pm 18,3 g/ người/ngày, không đạt nhu cầu khuyến nghị, ${ }^{6}$ nghiên cứu tại Bệnh viện đa khoa Thái Bình (2017) là 26,6 $\pm 3,9$ g/ngày ${ }^{15}$ và thấp hơn nghiên cứu của Hee-Sook $L$ và cộng sự tại Hàn Quốc năm 2015 là 49,7 $\pm 24,4 \mathrm{~g}$ g/người/ngày. ${ }^{16}$

\section{Lượng carbohydrate khẩu phần}

Đối với bệnh nhân thận nhân tạo chu kỳ nhu cầu carbohydrate cũng phải duy trì ở mức cân đối để đề phòng thiếu dinh dưỡng nhưng cũng không được làm tăng đường máu... Nghiên cứu của chúng tôi cho thấy lượng carbohydrate trung bình khẩu phần đạt 199,63 $\pm 43,82 \mathrm{~g} /$ người/ngày, đáp ứng $88,45 \%$ nhu cầu khuyến nghị. Kết quả này thấp hơn nghiên cứu của Hee-Sook L và cộng sự năm 2015 tại Hàn Quốc là 239,5 \pm 49,2 g/người/ngày ${ }^{16}$ nhưng cao hơn nghiên cứu của Trần Thị Yến (2018) tại Thái Bình, chỉ đạt 58,0 $\pm 9,0 \%$ nhu cầu khuyến nghị. ${ }^{6}$

\section{Vitamin, chất xơ và muối khoáng}

Kết quả trong nghiên cứu cho thấy lượng chất xơ trung bình khẩu phần đạt 5,89 \pm $2,80 \mathrm{~g}$, thấp hơn nghiên cứu của Sanlier $\mathrm{N}$ và Demircioğlu Y (2007) tại Ankara với lượng chất xơ trung bình khẩu phần $17,6 \mathrm{~g} \cdot{ }^{17}$ Các loại vitamin trong khẩu phần của bệnh nhân suy thận mạn chạy thận nhân tạo: Vitamin A là $409,58 \pm 447,43 \mu \mathrm{g}$, đạt $68,26 \%$ so với nhu cầu khuyến nghị; vitamin PP là 14,23 $\pm 5,44 \mathrm{mg}$, đạt $94,87 \%$ so với nhu cầu khuyến nghị; vitamin B2 là $0,78 \pm 0,27 \mathrm{mg}$, đạt $65 \%$ so với nhu cầu khuyến nghị; vitamin $B 1$ là 1,46 $\pm 0,61 \mathrm{mg}$ và vitamin C là $90,50 \pm 45,51 \mathrm{mg}$, đều đạt trên $100 \%$ so với nhu cầu khuyến nghị. Tỷ lệ bệnh nhân không đáp ứng đủ nhu cầu khuyến nghị của các loại vitamin cao: vitamin A $(81,81 \%)$, vitamin PP $(68,18 \%)$, vitamin B2 $(94,32 \%)$, vitamin C $(25,22 \%)$, vitamin B1 $(37,5 \%)$. Theo kết quả nghiên cứu hàm lượng các chất khoáng canxi, natri, phospho, kali lần lượt là 628,11 $\pm 631,48 \mathrm{mg} ; 1642,47 \pm 749,41 \mathrm{mg} ; 917,02$ $\pm 205,28 \mathrm{mg} ; 1710,51 \pm 574,53 \mathrm{mg}$. Lượng natri, phospho trong khẩu phần đều đạt theo nhu cầu khuyến nghị, riêng lượng canxi và kali khẩu phần không đạt, lần lượt là $62,81 \%$ và $85,5 \%$ so với nhu cầu khuyến nghị. Kết quả nghiên cứu của chúng tôi cao hơn nghiên cứu của Trần Thị Yến (2018) với hàm lượng canxi là 426,3 $\pm 243,2 g^{6}$; thấp hơn kết quả nghiên cứu của Hee-Sook L và cộng sự tại Hàn Quốc (2015) hàm lượng chất khoáng trong khẩu phần: Canxi 353,5 - 426,3mg, phospho 1033,9 - 1138,9mg; natri 3506,5 - 4695,9mg. ${ }^{16}$

\section{Tính cân đối của khẩu phần}

Nghiên cứu của chúng tôi cho thấy tỷ lệ $\mathrm{P}$ : L: G trong khẩu phần lần lượt là $21,64 \%$; $24,61 \%$ và $53,75 \%$, theo nhu cầu khuyến nghị của Viện Dinh dưỡng năm 2016 thì cơ cấu khẩu phần của bệnh nhân nên có $1-1,2 \mathrm{~g}$ protein/kg cân nặng, 20 - 30\% lipid, 55 - 65\% carbohydrate. ${ }^{8,9}$ Tỷ lệ protein động vật/protein tổng số là $67,36 \%$, lipid thực vật/lipid tổng số là $39,98 \%$, tỷ lệ này là cân đối so với nhu cầu khuyến nghị của Viện Dinh dưỡng năm 2016. Kết quả này cao hơn trong nghiên cứu của Trần Thị Yến (2018) tại Thái Bình có tỷ lệ protein động vật/protein tổng số là $59,1 \%$, lipid thực vật/lipid tổng số là $41,0 \pm 22,1 \%{ }^{6}$

Kết quả nghiên cứu của chúng tôi cho thấy tỷ lệ $\mathrm{Ca} / \mathrm{P}$ trong khẩu phần ăn của là 0,67 ; cao hơn kết quả nghiên cứu của Hee-Sook L (2015) tại Hàn Quốc $(0,34){ }^{16}$ Theo khuyến nghị của Viện Dinh dưỡng năm 2016, tỷ lệ $\mathrm{Ca} / \mathrm{P}$ nên $>0,8$; tốt nhất là 1 . Như vậy, kết quả trong nghiên cứu của chúng tôi chưa đạt so với nhu cầu khuyến nghị. Lượng vitamin B1/1000 kcal, B2/1000 kcal, PP/1000 kcal tương ứng là $1,01 \mathrm{mg} ; 0,54 \mathrm{mg}$ và $9,73 \mathrm{mg}$. Theo nhu cầu 
khuyến nghị về tính cân đối của khẩu phần thì cứ $1000 \mathrm{kcal}$ của khẩu phần cần có $0,5 \mathrm{mg} \mathrm{B1}$ và $0,6 \mathrm{mg} \mathrm{B2}$. Như vậy, tỷ lệ vitamin $B 1 / 1000$ kcal đạt, vitamin B2/1000 kcal không đạt so với nhu cầu khuyến nghị của Viện Dinh dưỡng.

Chế độ ăn có vai trò rất quan trọng trong phòng và điều trị bệnh suy thận mạn. Một khẩu phần hợp lý, cân đối giúp kiểm soát và dự phòng biến chứng, cải thiện được tình trạng dinh dưỡng, nâng cao chất lượng cuộc sống của bệnh nhân.

\section{KẾT LUẬN}

Nhìn chung khẩu phần ăn của bệnh nhân chưa cân đối, chưa đáp ứng đủ so với nhu cầu khuyến nghị dành cho bệnh nhân suy thận mạn chạy thận nhân tạo. Bệnh viện cần tăng cường công tác tư vấn, xây dựng chế độ ăn bệnh lý cho bệnh nhân.

\section{TÀI LIẸU THAM KHẢO}

1. Luyckx VA, Cherney DZI. Bello AK. Preventing CKD in Developed Countries. Kidney Int Rep 2019; 5 (3): 263-277.

2. Đinh Thị Thu Huyền, Phạm Thị Thu Hương, Nguyễn Thị Lý. Thực trạng tuân thủ chế độ dinh dưỡng của người bệnh suy thận lọc máu chu kỳ tại Bệnh viện Đa khoa Công an tỉnh Nam Định năm 2018, Tạp chí Khoa học Eiều dương 2019; 01(02): 35-40.

3. Ayodele OE. Burden of Chronic Kidney Disease: An International Perspective, Advances in Chronic Kidney Disease, 2010.

4. Bộ $Y$ tế. Hướng dẫn và chẩn đoán điều trị các bệnh Thận- tiết niệu năm 2015, Nhà xuất bản Y học, Hà Nội, 2015.

5. Wulandari $\mathrm{H}$; Susetyowati, Prasanto $\mathrm{H}$. Comparison between brief food frequency questionnaire and food record to assess the energy and protein intake of hemodialysis patients at Dr. Sardjito Hospital in Indonesia.
Saudi J Kidney Dis Transpl 2018; 29(1):145152.

6. Trần Thị Yến. Đặc điểm khẩu phần và một số rối loạn dinh dưỡng ở bệnh nhân suy thận mạn lọc máu chu kì tại hai bệnh viện tỉnh thái bình năm 2017, Luận văn Thạc sĩ chuyên ngành dinh dưỡng, Trường Đại học $\mathrm{Y}$ Dược Thái Bình, 2017.

7. Viện Dinh dưỡng. Các phương pháp điều tra và đánh giá khẩu phần. Nhà xuất bản $\mathrm{Y}$ học, Hà Nội, 2017.

8. Viện Dinh dưỡng. Hướng dẫn chế độ ăn bệnh viện, Nhà xuất bản Y học, Hà Nội, 2016.

9. Viện Dinh dưỡng. Nhu cầu khuyến nghị dinh dưỡng cho người trưởng thành Việt Nam, Nhà xuất bản Y học, Hà Nội, 2016.

10. Viện Dinh dưỡng. Hệ số sống chín và bảng chuyển đổi thực phẩm, Nhà xuất bản $Y$ học, Hà Nội, 2017.

11. Segall L, Mardare NG, Ungureanu S and et al. Nutrition status evaluation and survival in haemodialysis patiens in one centr from Romania. Nephrol Dialysis Transplant 2009; 24(8): 24-40.

12. Beberashvili I, Azar A, Sinuani I and et al. Objective Score of Nutrition on Dialysis (OSND) as an alternative for the malnutritioninflammation score in assessment of nutritional risk of haemodialysis patients. Nephrol Dial Transplant 2010; 25(8): 2662-2671.

13. Fiaccadori E, Sabatino A, Barazzoni R, Carrero JJ and et al. ESPEN guideline on clinical nutrition in hospitalized patients with acute or chronic kidney disease, Clin Nutr. 2021; 40(4): 1644-1668.

14. Vaz IM, Freitas AT, Peixoto Mdo R and et al. Is energy intake underreported in hemodialysis patients? J Bras Nefrol 2015; 37(3): 359-66.

15. Trần Khánh Thu, Lê Bạch Mai, Phạm 
Duy Tường. Kiến thức, thực hành dinh dưỡng và đặc điểm khẩu phần của người bệnh suy thận mạn lọc máu chu kỳ tại bệnh viện đa khoa tỉnh Thái Bình, Tạp chí Y học thực hành 2017; 1043 (5): 118-120.

16. Hee-Sook L, Hee-Seon K, Jin Kuk K and et al. Nutritional Status and Dietary Management
According to Hemodialysis Duration, Clin Nutr Res 2019; 8(1): 28-35.

17. Sanlier N, Demircioğlu Y. Correlation of dietary intakes and biochemical determinates of nutrition in hemodialysis patients. Ren Fail 2007; 29(2): 213-8.

\section{Summary}

\section{DIETARY INTAKE IN CHRONIC KIDNEY DISEASE PATIENTS UNDERGOING HEMODIALYSIS IN HAIPHONG MEDICAL UNIVERSITY HOSPITAL IN 2021}

A cross-sectional study was conducted on 88 patients with chronic kidney disease, who were undergoing hemodialysis in Haiphong Medical University hospital, from January 2021 to May 2021 to assess their dietary intake. A 24-hour recall method was used to investigate the food intake. Research results showed that the daily calorie intake was $1470.54 \pm 238.2 \mathrm{kcal} / \mathrm{day}$; the amount of protein, lipid, and carbohydrate in the diet were $78.34 \pm 14.77 \mathrm{~g} /$ day, $40.62 \pm 15.01 \mathrm{~g} / \mathrm{day}, 199.63 \pm$ $43.82 \mathrm{~g} /$ day, respectively. The amount of protein and lipid reached the recommended range, energy reached $87.99 \%$, carbohydrate reached $88.45 \%$ of the recommended range. The proportions of protein: lipid: carbohydrate was 21.64: 24.61: 53.75; the amount of vitamin B2/1000kcal was 0,54 mg, which were not balanced compare with the Recommend Dietary Allowance. The ratio of protein from animal/protein total was $67.36 \%$; lipid from vegetables/lipid total was $39.98 \%$; the amount of vitamin $\mathrm{B} 1, \mathrm{PP} / 1000 \mathrm{kcal}$ were $1.01 \mathrm{mg}$ and $9.73 \mathrm{mg}$ respectively, which were in balance with recommended range. We suggest that it is necessary to strengthen dietary counseling for patients.

Keywords: dietary, chronic kidney disease, hemodialysis. 